\title{
XXIV. Descriptions of new Coleoptera from East Africa and Madagascar. By Chas. O. WATERHOUSE.
}

[Read November 5th, 1879.]

I HAVE to submit to the Society this evening descriptions of some beautiful Coleoptera from East Africa and Madagascar. One is a species of Sternocera, the second is a remarkable new genus of Longicorns from Madagascar.

The following are the descriptions:-

\section{BUPRESTID Æ.}

\section{Sternocera PULCHRA.}

Thorace cupreo, albo-fasciculato; elytris viridi-æneis, vittâ obliquâ purpureâ, sub humero maculâ fulvo-tomentosâ.

Long. 22 lin.

A most beautiful species, perhaps most nearly allied to S. funebris, Bohem. Thorax bright coppery, very deeply and closely foveate, each fovea with a short tuft of yellowish-white soft hair; the extreme lateral and basal margins blue. Elytra bright green, strongly and thickly punctured, the punctures irregular in form and not arranged in regular lines, filled with extremely fine pale pubescence; beneath each shoulder there is an elongate orange tomentose spot; on each elytron there are the following purple markings or shades, viz., a spot in the middle of the base, a stripe placed a little behind the orange spot, on the margin directed obliquely upwards, and a rather broad streak commencing on the margin a little behind the middle of the elytra, directed for a short distance obliquely upwards and then suddenly bent downwards, obliquely, towards the suture. These purple marks are only visible in certain lights. The underside of the insect is coloured with purple, golden-green and blue-green, and has some patches of fine pale pubescence.

Hab.-Mountains of Usangara. Coll. Brit. Mus.

TRANS. ENT. SOC. 1879.-PART IV. (DEC.) 


\section{CERAMBYCID $\mathbb{E}$.}

\section{CHLIDONIN}

\section{Chlidones.}

Head distinctly broader than the thorax, nearly round, evenly arched from the neck to the clypeus, cheeks extremely short. Eyes very widely separated, not very finely granulated, semicircularly emarginate above. Antennæ placed in a pit in the emargination of the eye (the margins of this pit not raised above the level of the forehead), extending to the middle of the elytra, slender; the basal joint elongate, subcylindrical ; the 2 nd joint very small, the 3rd as long as the 1st, but much more slender, a little swollen at the juncture with the 4th, which is of the same form and length; the 5 th is a quarter longer; the 6th to 9th joints are a little shorter than the 3rd, not quite so cylindrical; the 10th and 11th joints are a little shorter. Thorax narrower than the head, twice as long as broad, somewhat flattened above, moderately constricted before the middle and before the base. Scutellum parallel at the sides, rounded at the apex. Elytra a little broader than the head, but rather narrowed in the middle, flat above at the base, square-shouldered, declivous at the apex. Prosternum rather narrow, regularly arched; mesosternum between the coxæ broader than long, flat, but sloping a little anteriorly; metasternum about as long as broad, its parapleuræ very narrow, gradually narrowed to the apex, concave. Legs very long, the femora very gradually and slightly thicker in the middle. Tarsi slender, the basal joint of the intermediate pair longer than the three following taken together.* Abdomen in the female gradually acuminate to the apex, the intercoxal process narrow, acuminate, the basal segment long, the following segments decreasing in length.

This genus is one of the many remarkable forms occurring in Madagascar, for which it is extremely difficult to find a satisfactory position. Its general appearance is something between Cylindrepomus (Lamiida) and Sclethrus, but its affinities appear to be with the Tillomorphince, or Clytince, and I propose to place it after this latter family.

* The posterior pair are wanting. 


\section{Chlidones lineolatus, n. sp.}

Elongatus, angustus, niger, opacus ; antennarum articulis apicalibus basi, femorumque apice ferrugineis, thorace lateribus lineâ obliquâ et utrinque ad basin puncto parvo albis, elytris abdomineque lineolis nonnullis abidis.

Long. $8 \frac{1}{2}$ lin.

Head thickly and rather strongly punctured, with a fine impressed longitudinal line in front. Thorax thickly and strongly punctured, with a smooth line in the middle (not reaching the base or apex) and a shorter smooth line on each side; there is a round white spot on each side at the base, and a white line on each side, these two lines are united below by a white line in front of the coxæ. The elytra are rather thickly punctured, dull velvety except at the shoulders and apex; each elytron has a short white line at the scutellum, a spot in the middle, and an oblique white line beyond the middle. There is a white line at the side of the mesosternum, a broader band of white along the anterior border of the metathorax, a short line on the parapleuræ; the abdomen has a short white line on the intercoxal process, an oblique line on each side of the basal segment (these last joined together at the apex of the segment), and a band of white at the apex of the second segment.

Hab.-Fianarantsoa (Mr. Shaw). 


\section{$2 \mathrm{BHL}$ Biodiversity Heritage Library}

1879. "XXIV. Descriptions of new Coleoptera from East Africa and Madagascar. By Chas. O. Waterhouse." Transactions of the Entomological Society of London 27, 319-321.

https://doi.org/10.1111/j.1365-2311.1879.tb01998.x.

View This Item Online: https://www.biodiversitylibrary.org/item/48188

DOI: https://doi.org/10.1111/j.1365-2311.1879.tb01998.x

Permalink: https://www.biodiversitylibrary.org/partpdf/35700

\section{Holding Institution}

Smithsonian Libraries

\section{Sponsored by}

Smithsonian

\section{Copyright \& Reuse}

Copyright Status: Public domain. The BHL considers that this work is no longer under copyright protection.

This document was created from content at the Biodiversity Heritage Library, the world's largest open access digital library for biodiversity literature and archives. Visit BHL at https://www.biodiversitylibrary.org. 